DOI: $10.17516 / 1997-1370-0618$

УДК 7.038.6

\title{
The National and the International in Three Works of Contemporary
} Chinese Artists

\author{
Aleksandra A. Sitnikova* \\ Siberian Federal University \\ Krasnoyarsk, Russian Federation
}

Received 05.05.2020, received in revised form 05.06.2020, accepted 15.06.2020

\begin{abstract}
The article formulates and analyses a hypothesis, according to which, thanks to modern postmodern art, a single international visual language was formed in the late 20 th - early 21 st centuries, and previously mysterious and incomprehensible foundations of national culture became accessible and open at the international level. This concept is considered on the basis of the international popularization of Chinese art, as the Chinese national culture and art remained mysterious for Western audiences for many centuries. The mechanisms of popularizing national culture are disclosed in the article based on an analysis of three works created by famous contemporary Chinese artists - Odyssey by Cai Guoqiang, Coloured Vases by Ai Weiwei and Last Supper by Zeng Fanzhi.
\end{abstract}

Keywords: avant-garde Chinese art, Cai Guoqiang, Zeng Fanzhi, Ai Weiwei, traditional Chinese art, modern Chinese art.

Research area: theory and history of art.

Citation: Sitnikova, A.A. (2020). The national and the international in three works of contemporary Chinese artists. J. Sib. Fed. Univ. Humanit. Soc. Sci., 13(6), 951-962. DOI: 10.17516/1997-1370-0618.

(C) Siberian Federal University. All rights reserved

* Corresponding author E-mail address: sem_dobrianka@mail.ru ORCID: 0000-0002-1622-2797 


\section{Introduction}

From the last decade of the $20^{\text {th }}$ century until this year, Asian art, in particular, Chinese, Korean, Japanese, began to occupy a leading position in the international art scene. Each country occupied certain cultural "niches" where it became a leader. South Korea has been at the forefront in the field of cinema (this is confirmed, at least, by the 2019 "Golden Palm" that undoubtedly went to the film "Parasites" by Bong Joon-ho). Japan is home to the manga comics with teenage fans around the world, as well as a number of well-known contemporary artists - for example, Yayoi Kusama, who in the film "Kusama: Endless Worlds" complains that, in fact, in 1960's when she joined the Fluxus movement, her ideas with soft sculptures were "stolen" by Claes Oldenburg, and her creative work remained unknown, while in the 2000's she became considered as one of the greatest contemporary artists in the world, and major museums of the world wanted to get her works; Takashi Murakami, who managed to turn nuclear explosions, the experienced collective tragedy of Japan and the whole world into a pop brand; Chiharu Shiota and others. In turn, China is home to a significant number of contemporary artists who are among the best and most expensive artists in today's art platform - these are Cai Guoqiang, Ai Weiwei, Zeng Fanzhi, Zhang Huan, Huang Yongping, Liu Bolin and a number of other artists.

The purpose of this article is to analyse some universal mechanisms for popularizing national cultural features that are used by contemporary artists at the international level. We will focus on works of art created by Chinese artists as a material for the analysis of such cultural mechanisms. Chinese contemporary art was chosen for the analysis, since it remained completely mysterious, incomprehensible, distinguished by rare craft practices for a long time, but today, thanks to the efforts of Chinese artists, many of the "secrets" of Chinese culture have become clear and accessible to the international community.

The article analyses such works as Odyssey by Cai Guoqian, Coloured Vases by Ai Weiwei and The Last Supper by Zeng Fanzhi; identifies the artistic methods that reveal national cultural "secrets" to the world community, thus forming a single global world.

\section{Methodology}

The study is based on a bibliographic analysis, which implies the study of modern scientific publications about Chinese art - both foreign and Russian, published in journals, peer-reviewed by the authoritative databases Scopus, Web of science and RSCI. The philosophical and art-history analysis, developed by professors V.I. Zhukovskii and N.P. Koptseva (Zhukovskii, Koptseva, 2004) at the Chair for Cultural Studies and Art History of the Institute of the Humanities of Siberian Federal University to interpret the artistic images of three works created by contemporary Chinese artists.

\section{Analytical Review}

There are several kinds of the modern Chinese art. Firstly, the ancient traditional art of "Guohua" continues to exist and is actively developing, and it turns, rather, into souvenir export products, since even Western spectators and tourists are interested in the aesthetics of "Guohua" - ink wash painting - as a sign of the authenticity of Chinese culture: "Thus, in the modern culture of China, traditional painting remains relevant in many areas of society's life, acting as an object of investment, a source of inspiration for artistic creativity, an ethnic brand in the cultural industries, a heuristic element of synthetic kinds of art, including those based on modern computer technology" (Ivanova, Iakovleva, 2013: 235).

Secondly, in the $20^{\text {th }}$ century, as a result of active cooperation between the PRC and the USSR after 1949, oil painting became one of the main art techniques in the country. In the scientific literature, especially Russian, there are an extremely large number of publications devoted to the history of the development of oil painting in China and its current state. They necessarily focus on the educational method of P.P. Chistiakov and educational activities of K.M. Maksimov, and analyse the works of students and modern successors of the traditions of "socialist realism" in Chinese art (Lv, 2011; Wang, 2013; Xiaobin, 2017; 
Bogodelina, 2018). In detail, the history of oil painting in China from the $17^{\text {th }}$ century to "village realism", "scar art", and finally, the most widely known "cynical realism", is described and presented in Guo Xiaobin's thesis research titled "The Influence of Russian and Soviet Realistic Painting in China of the 1950-1960's: receptions and traditions." The history of oil painting in China is of great interest to contemporary critics, since if in the 1980's and 1990's, when Chinese art was just beginning to enter the international art platform, art historians paid attention primarily to pro-Western Chinese art based on the avant-garde art traditions of the $20^{\text {th }}$ century, which is close to the aesthetics of postmodernism, then Chinese painting soon began to gain wide popularity and value in the art market - for example, paintings by Zeng Fanzhi, Yue Minjun and others.

The most famous at the international level is another type of Chinese contemporary art, which is based on the avant-garde traditions of the $20^{\text {th }}$ century, primarily pop art, as the avant-garde was "brought" to China in 1985 by Robert Rauschenberg; art of a postmodern nature; "unofficial" Chinese art, since the national version of "socialist realism" is recognized as official. The names of Chinese postmodern artists are popular at the widest level, as evidenced by the large number of journalistic texts about their work in printing and online mass media - these are Ai Weiwei, Cai Guoqiang, Liu Bolin, Zhang Huan and others. The general characteristics of this type of art, its development trends and description of the creative work of leading masters are presented in several monographic studies and articles in Russian and English (Zhong, 2014; Andina \& Onnis, 2019; Kee, 2018; Dubrovskaia, 2018; Quas, 2017; Neglinskaia, 2010). Comparing the sociocultural conditions of the existence of Soviet and Chinese "unofficial" art, E.A. Kartseva draws attention to an important difference: "China that has transformed toward a developed market economy is also rapidly changing with respect to the once non-conformist art, which has come under the scrutiny of the West. State censorship is becoming less authoritarian, the party's government tends to promote a
Chinese product that can make money" (Kartseva, 2017: 159).

Since the main attention in the article will be focused on the analysis of the works of such artists as Cai Guoqiang, Ai Weiwei and Zeng Fanzhi, it is also worth pointing out some scientific publications dedicated specifically to their work. The creative path of the artist Cai Guoqiang and the analysis of his key works are described in the articles of such authors as Zhong Y. (Zhong et al., 2014), Neglinskaia M.A. (Neglinskaia, 2020), Jingyu Sh. (Jingyu, 2019). The article by Starkman Ch. (Starkman, 2010) is of particular relevance in the context of this study, since the author describes the process of creating the work titled Odyssey, which we are going to analyse in this article. Ai Weiwei is probably one of the most famous artists in China today, so it is not surprising that a huge number of journalistic texts around the world, as well as scientific research works are devoted to him. Examples of foreign scientific research works include Sorace Ch. (Sorace, 2014), Menezes C. (Menezes, 2011); among Russian texts - Faryno J. (Faryno, 2018), Pashuk A.A. (Pashuk, 2015) and others. Regarding the creative work of Zeng Fanzhi, due to a record-high sale - the highest price for a work of Asian art there are many journalistic articles in both the Western and Russian press: for example, on the Public delivery web-resource (Public delivery, 2019) or in the article by T. Gorbutovich (Gorbutovich, 2014). Serious attention is also paid to the work of this artist in scientific research literature (Vial-Kayser, 2015; Gultekin, Peker, 2016). the article by Vial-Kayser Ch. Is particularly significant in the context of this study, since it carried out a detailed art review of The Last Supper, which is in the centre of our interest.

\section{Analysis of Odyssey by Cai Guoqiang}

Cai Guoqiang was born in 1957 in Quanzhou. He received a professional art education, initially worked as a stage designer at the Shanghai Institute of Drama. In 1985 he emigrated to Japan, and later to New York, where his studio is located today. Starting his work with traditional painting, Cai Guoqiang gained fame for his "powder" painting. The most 
spectacular in his work is the creation of conceptual fireworks that add up to amazing figurative paintings. The conceptual approach is expressed in the fact that he carefully refers to the choice of locations for his powder shows for example, his modest, when compared with the scale of future fire shows, project "Age of Mushroom Clouds", when he shot gunpowder in the form of a nuclear explosion, was conducted in the background of the recognizable New York landscape, in Nevada, where nuclear tests had previously been conducted, as well as in Hiroshima. In addition to multi-coloured paintings of fireworks, he also creates planar "drawings" choosing an unconventional material - burning gunpowder. In postmodern art, turning to atypical art materials to create works of art is the most common technique, but a conceptual explanation of the use of strange materials is always required - in this case, Cai Guoqiang emphasizes several aspects at once: he grew up in a city where they specialized in the production of gunpowder from the time of the Cold war, so this material was well known to the artist since childhood, and China is also known as the country of the invention of gunpowder, as a country where fireworks and the culture of fiery performances are appreciated.

We chose the 49-meter ( $3.15 \times 49.38 \mathrm{~m})$ painting "Odyssey" created by the artist in 2010 for the Museum of Fine Arts in Houston as a work, based on the analysis of which it seems to us that the indicated problem can be best solved (Fig. 1, 2).

This work emerged as a result of the fact that the curator of the museum, where there is an extensive collection of ancient Asian art, developed a concept according to which ancient art must be displayed in a dialogue with the contemporary art, so that viewers feel the connection of times and understand how the past responds to the present. The realization of this concept began with an exhibition of Korean art, where one of the most famous Korean artists, Do Ho Suh, participated, and in 2010, Cai Guoqiang was invited to create his own work to display the Chinese collection. He presented the traditional gunpowder drawing on 42 panels of chipboard, on top of which hemp paper is glued - these panels

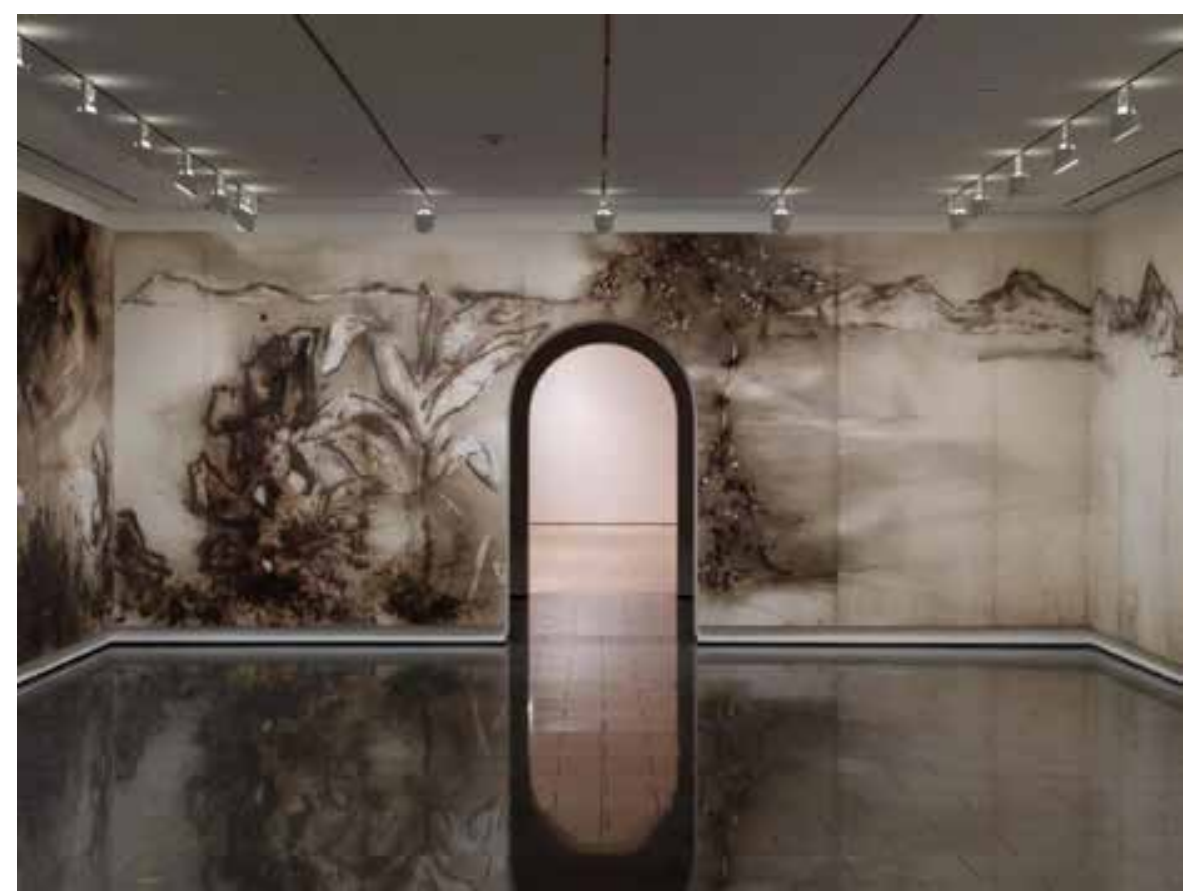

Fig. 1. Cai Guoqiang, Odyssey, 2010, gunpowder and pigment on paper, the Museum of Fine Arts, Houston (c) Cai Guoqiang. Available at: https://www.mfah.org/art/departments/arts-asia 


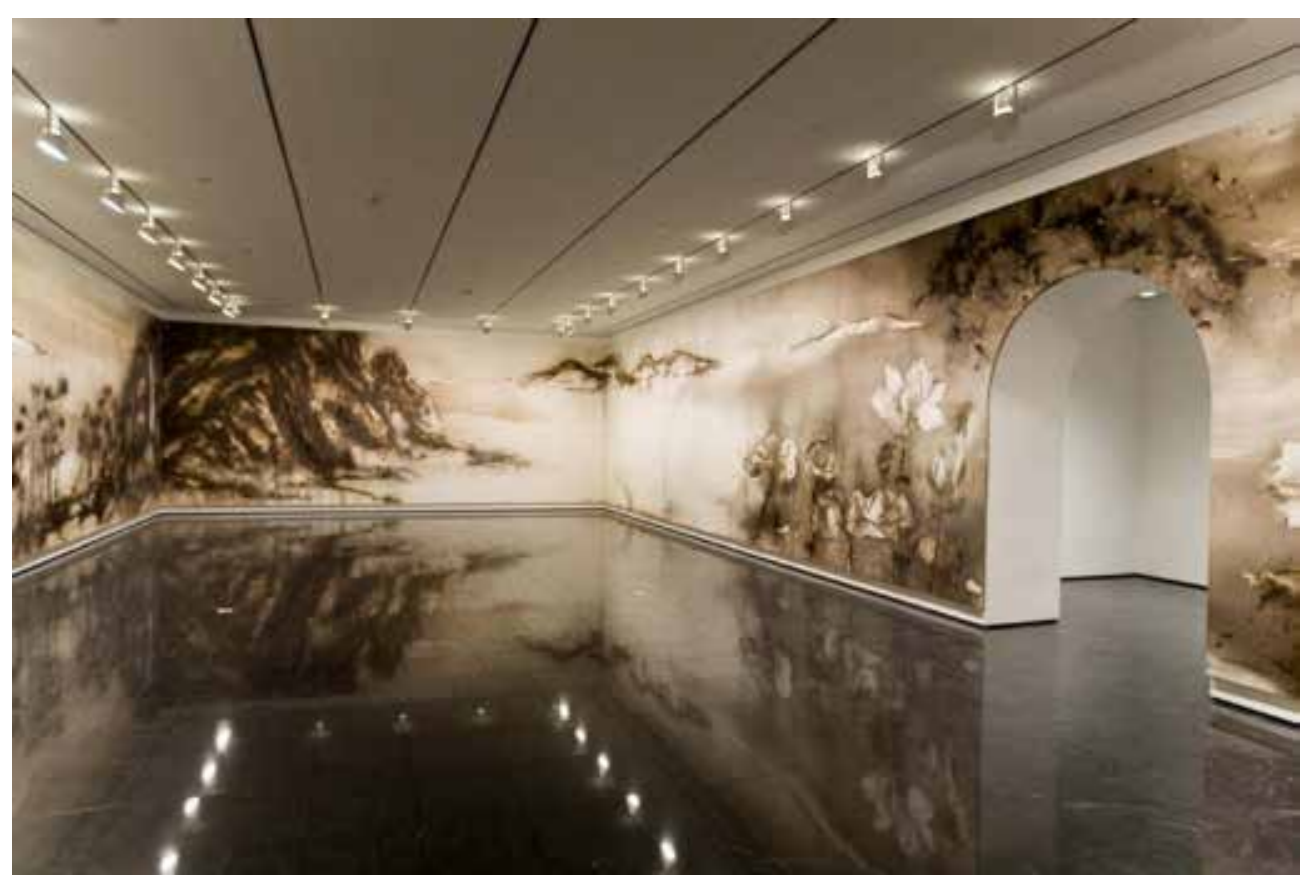

Fig. 2. Cai Guoqiang, Odyssey, 2010, gunpowder and pigment on paper, the Museum of Fine Arts, Houston (c Cai Guoqiang. Available at: https://caiguoqiang.com/projects/projects-2010/odyssey/

completely cover the walls of the exhibition room, which also has two arched openings for entrance and exit. Cai Guoqiang presented a "powder" painting in the landscape genre that is traditional for Chinese art of Guohua "shan shui": indeed, images of mountains and water, symbolizing yang and yin are the main plot of the image; also the painting is filled with traditional "characters" of Chinese painting - peony flowers and lotus, images of pines and bamboo. All of them symbolize the noble qualities that the room is filled with: peonies wealth, lotus - purity, pine trees - firmness and longevity, bamboo - determination, etc. The interpretation of these symbolic signs in Chinese art is very often given in articles about the Gohua painting - for example, S.A. An (An, 2010). The postmodern artist in his art addresses the ancient origins of national Chinese painting. In this case, the interpretation of the name "Odyssey" suggests the following: a character of Greek mythology Odysseus wandered around the seas for a long time in search of the way back to his home, to his homeland - here the experimentalist artist who emigrated from China to the USA returns in his art to the "alphabet", the foundations of the traditional Chinese painting. In addition to symbolism, the black-and-white aesthetics of drawing on paper, the work reveals a number of features typical of Gohua: the elongation of the drawing in length, the ability to read it as a scroll, as well as the modest embeddedness of a human figure into the image - usually in Chinese landscapes a man is barely noticeable, but here this technique is solved interactively: entering the exhibition hall through the arch, a viewer is involuntarily integrated into the universal natural space.

Thus, Cai Guoqiang, with his unique technique also rooted in Chinese culture, his fame on the world art arena and the scale of his work, draws attention of a modern viewer to understanding Chinese painting: a viewer is given a way to symbolically read the landscape and its elements (flowers, trees), the basics of Eastern Buddhist philosophy, where opposites always exist in the process of transformation into each other, and as a result of destruction, creation occurs (destruction of paper by fire, explosions 
of gunpowder, leads to the creation of landscape).

\section{Analysis of "Coloured Vases" by Ai Weiwei}

Ai Weiwei was born in 1957 in Beijing. He received education in Beijing and New York. He lived in New York from 1981 to 1993. In the 2010's, he was recognized as one of the most influential artists in the world. He works in various media - from video to the creation of large-scale installations. He became widely known as a revolutionary artist, dissident artist, a member of the art group called the "Stars", which is considered as the beginning of the history of non-conformist art in China. Ai Weiwei is known for his work raising the problems of modern totalitarian states, the problems of social injustice, the problems of international injustice and the economy. In one way or another, he almost always turns to traditional Chinese crafts and things to create his works: sewing clothes by low-paid Chinese workers for the whole world; Chinese migrants, whose very existence has been turned into a work of art; unique Chinese craftsmanship for creating three-legged stools; a bicycle as a typical means of transportation in China, etc. One of the key materials in the artist's work is traditional Chinese porcelain, a craft for the manufacture of porcelain vases. Ai Weiwei often turns to this material - in particular, in his most famous work "Sunflower Seeds" for the Turbine Hall of Tate modern, created in 2010, when he gave work to the Chinese masters, who previously specialized in the manufacture of imperial porcelain, but in the $21^{\text {st }}$ century their skills became unwanted. They manually produced porcelain seeds that Tate modern visitors in London were allowed to walk on. Since the 1990's, the famous Chinese craft for the manufacture of porcelain vases has been a significant theme in the artist's work: for example, in 1995 he created one of his most famous works "Dropping a vase of the Han Dynasty" (Fig. 3).

In this work, he destroyed an expensive vase of a great cultural and historical value and documented this fact. This work is included in the "alphabet" of postmodern art of the turn of the $20^{\text {th }}-21^{\text {st }}$ centuries. It has been repeatedly cited by other artists. The second version of the transformation of a porcelain vase in the artist's work is the inscription "Coca-Cola" on it (Fig. 4).

The third example of working with vases is "Coloured Vases", 2006 (Fig. 5).

In all three versions, a viewer observes the fact of the destruction of the ancient, traditional, famous past by various means: through the direct destruction, through destroying an ancient artifact with an advertising design, through colouring the ancient ceramic art in the spirit of abstract painting, abstract expressionism. In fact, in all three works, we observe the destruction of the past by the culture of the $20^{\text {th }}$ century. Despite the fact that Ai Weiwei
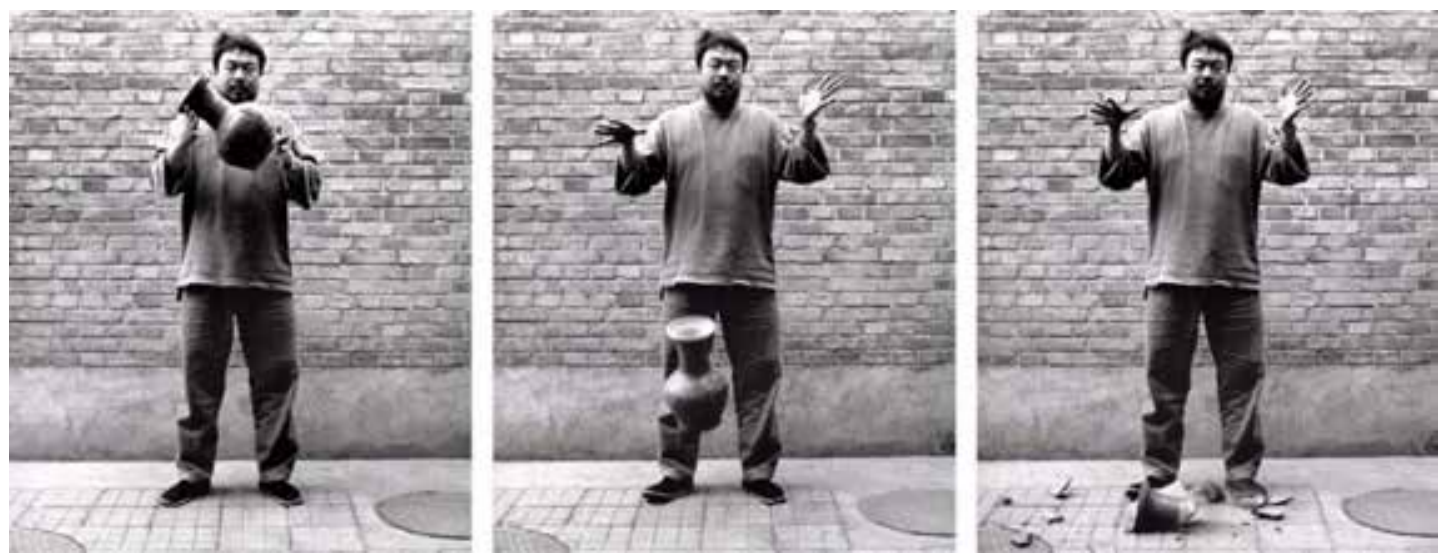

Fig. 3. Ai Weiwei. Dropping a Han Dynasty Urn. Photographic documentation of the performance. 1995. Available at: https://artchive.ru/artists/78922 Aj_Vejvej/works/544824 Ronjaja_vazu_dinastii_Khan\%27 


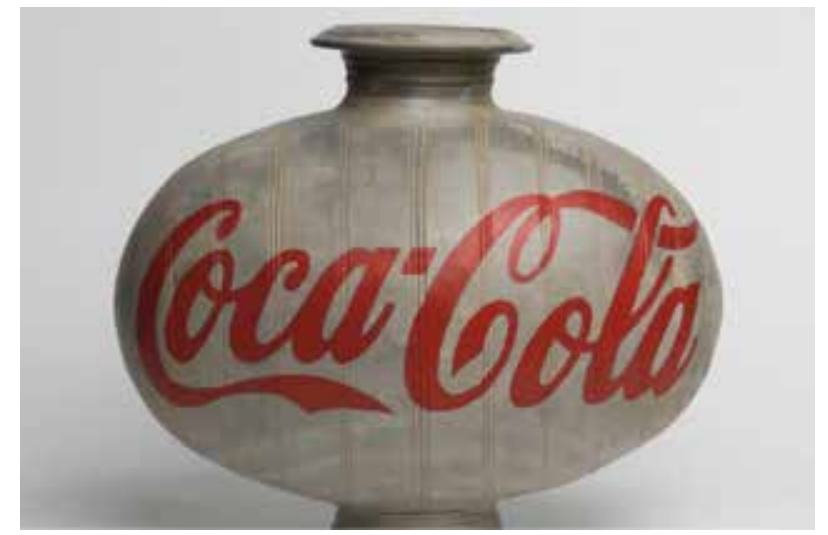

Fig. 4. Ai Weiwei. Coca-Cola vase. 2014. Signed and dated 'Weiwei 2014' on the underside painted Han dynasty vase (206 BC-220 AD)

$35 \times 50 \times 27$ cm. Available at: https://www.phillips.com/detail/ai-weiwei/UK010119/17

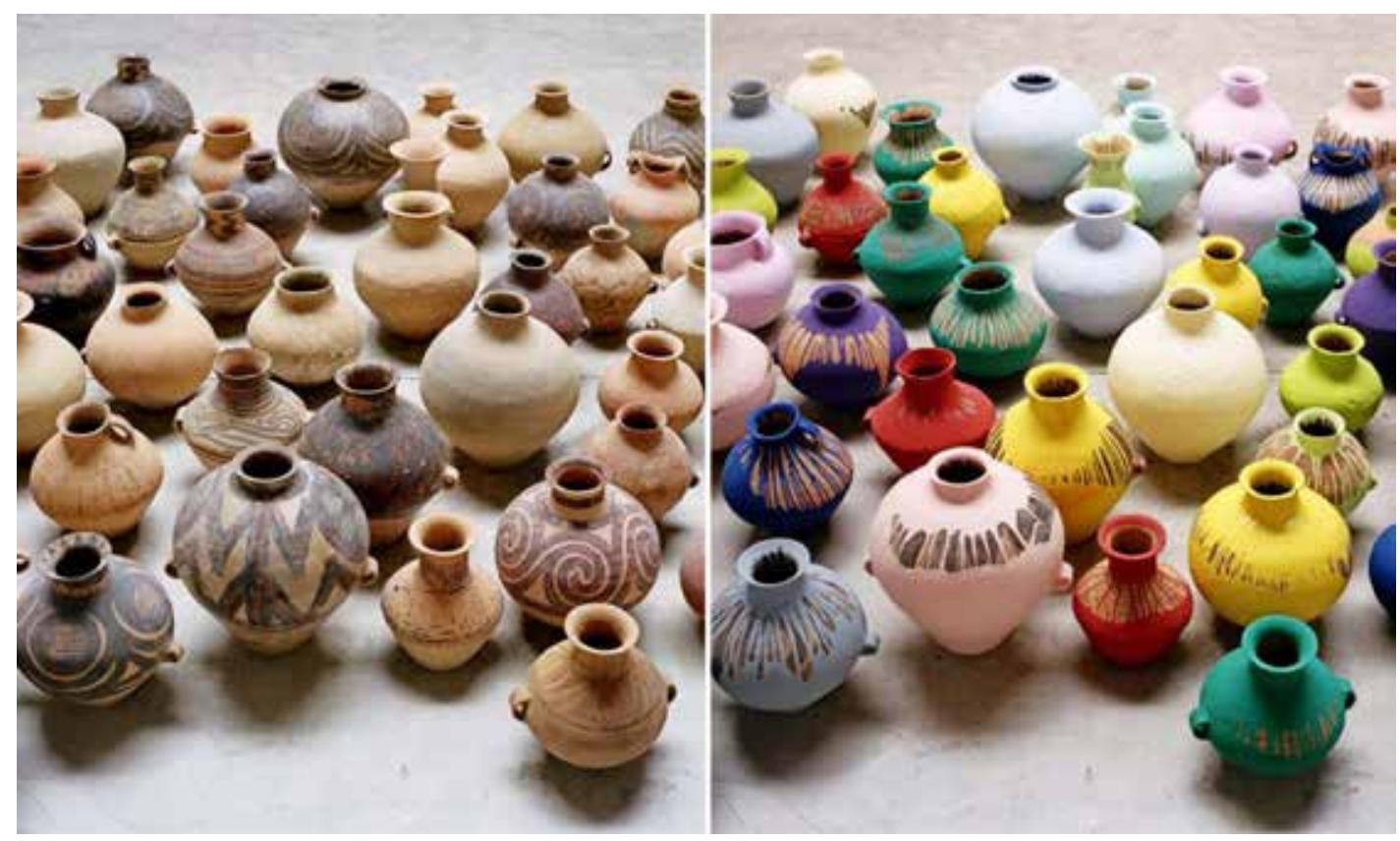

Fig. 5. Ai Weiwei. Coloured vases. 2006. 51 ancient vases coloured by paint

is often condemned for the vandal nature of these works, he skilfully confronts the viewers with the very fact of destruction forcing them to somehow experience it - to feel sorry for the great past; to hate the one who does this and, in this case, to provoke the protection of the heritage of the past; or, conversely, to support the idea of destroying the past for the present. Ai Weiwei chooses the famous national Chi- nese craft as a material for demonstrating destruction and demonstrates the nature of the impact of the global culture of the $20^{\text {th }}$ century on it.

\section{Analysis of "The Last Supper" by Zeng Fanzhi}

Zeng Fanzhi was born in 1964 in Wuhan. He received his art education at the Hubei 


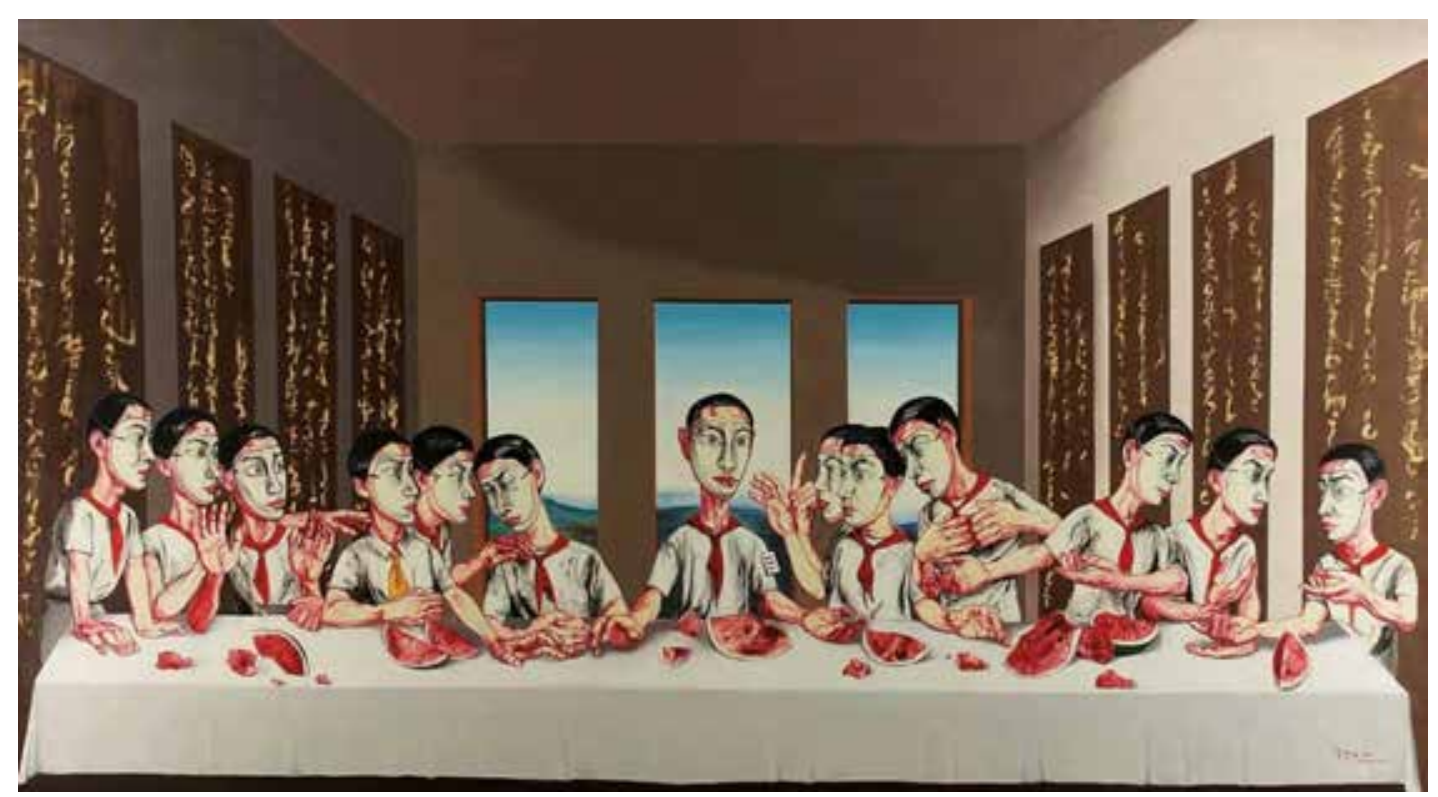

Fig. 6. Zeng Fanzhi. The Last Supper. 2001 Oil on canvas. 220 x 395 cm. Available at: https://gorbutovich.livejournal.com/53902.html

Academy of Arts. Now he lives and works in Beijing. He is recognized as one of the most expensive contemporary artists in China, since in 2013, his painting "The Last Supper" (Fig. 6) was sold at Sotheby's auction in Hong Kong for a record amount.

On the one hand, unlike Cai Guoqiang and Ai Weiwei, Zeng Fanzhi is in a different creative situation - he did not emigrate from China, but continues to work in Beijing, and also works in the tradition of figurative oil painting, that is, he does not turn to new genres in contemporary art - installations, video art, performances - and also does not experiment with art materials, while remaining committed to traditional painting. On the other hand, his art also originates from the avant-garde art practices of the beginning of the $20^{\text {th }}$ century - from the expressionism painting, where the realistic image is distorted in order to express the person's inner experiences. In the early 1990's, he gained fame thanks to his "Hospital Series", and in the late 1990 's, his second highly rated series with masks was created. "The Last Supper", created in 2001, is considered by many experts to be the main symbol of modern Chinese art: it is an interpretation of the famous fresco of the same name by Leonardo da Vinci in Milan based on modern Chinese realities.

Zeng Fanzhi's "The Last Supper", recreates the composition by Leonardo da Vinci, where 13 characters are seated at the table: a character in the centre is surrounded by 12 others. The easily recognizable similarity of the works ends at the compositional level, and the differences are as follows: instead of Christ surrounded by his apostles at the table, there are characters in white masks and costumes of pioneers of the communist era (red ties and white shirts), the action takes place, presumably, in the hall for public meetings, where communist slogans in Chinese are hung on the walls. The vanishing point of lines, like that of Leonardo da Vinci, is a window behind which the landscape is visible; there are numerous bright red watermelons on the table; among the pioneers there is only one different character who, instead of a red pioneer tie, is wearing a yellow business tie, and his white shirt has a pocket, plus to everything he is not included in the group with any other character, while all the others are grouped in two or three people traditionally this character is compared with Judas. At the Sotheby's auction, the meaning 
of this work was interpreted by art historians as the history of political changes in China, where the communist regime was betrayed by the capitalist regime. The scientific study of $\mathrm{Vi}$ al-Kayser Ch. (Vial-Kayser, 2015) reveals the political basis of this work, as the author compares "The Last Supper" of 2001 with the earlier work of Zeng Fanzhi with the same name and composition, but with Mao in the place of Christ and Judas. She also publishes watercolor sketches of this work, which shows that the action was originally supposed to take place in the Communist Party meeting room, where red banners are placed in the background (the landscape appeared already in the final version of the work, painted in oil) and photographs of real meetings of the Communist Parties, which really related to the composition of "The Last Supper." In the work of Zeng Fanzhi, a significant emphasis is placed on hands: in the film about his creative work, the author himself tells that he was always interested in the inner, emotional life of people, but for the Chinese society at the end of the $20^{\text {th }}$ century it was not customary to express their emotions openly, so there are masks in his works, which is depersonalizing people; white (the colour of mourning in Chinese culture) masks hiding their inner experiences, therefore, to a greater extent, the artist emphasizes the movements of hands painted with bright red contours that also express the inner life of a man. Indeed, observing the gestures of the hands, we understand that there is an emotionally intense dispute at the table, the characters express their true feelings with their hands: the central character is completely calm - his hands rest calmly on the table, the palm of his left hand is confidentially open to a viewer, his right hand is clenched in a fist; the characters on the right side, one by one, express different feelings with hand gestures someone in adoration tries to touch the person in the centre, the other points to his forehead emphasizing the importance of rational understanding of what is happening, the third holds on to his heart emphasizing the heartiness of his feelings; the fourth and the fifth emotionally point to the person in the centre, prove something trying to convince the person on the far right from something. The characters on the left whisper about something, demonstrate their open palms to the viewer emphasizing the purity of their thoughts, resolutely rise from the table, perhaps preparing to say something important; the character wearing a yellow tie clenched his hand in a fist and sternly looks towards the man in the centre. Thus, things are humming at the table, a debate is being held about the most important beliefs in life. Vial Kayser Ch. (Vial-Kayser, 2015) in his study also draws attention to the fact that the argument at the table during the meal is an important and characteristic part of Chinese culture, which the author expressed in his work. The fact that bread and wine that are traditional for the Christian version are replaced with watermelons is explained as the culture of China, where watermelon is the most affordable and widespread food of poor people (the artist himself at a time when he was very short of money, often ate only watermelons), as well as by the aesthetic reasons: the artist actively uses red as the colour of blood and flesh, which also corresponds to the concept of "The Last Supper", the essence of which lies in the fact that Christ shared his flesh and blood with his disciples.

Thus, Zeng Fanzhi uses the following techniques to tell about the features of national culture at the international level: referring to the most famous works in the history of art in his paintings, which allows the Western audience to immediately begin to look for differences in the works and at the same time understand new meanings, and, secondly, he is actively addressing the representation of the socio-cultural and political realities of his country, which are of interest to the world community.

\section{Conclusion}

The purpose of the article was to understand how contemporary art makes mysterious national and ethnic cultural codes that were previously clear only to members of a particular national or ethnic community accessible and understandable. The article attempts to understand such mechanisms on the basis of the study of Chinese contemporary art, since this culture remains not fully known to Westerners until today. For this, three works of Chinese artists working in line with the postmod- 
ern paradigm were analysed - "Odyssey" by Cai Guoqiang, "Coloured Vases" by Ai Weiwei and "The Last Supper" by Zeng Fanzhi. As a result of the study, it was revealed that contemporary art uses such methods to ensure global understandability and accessibility of national cultural codes as: 1) the effectiveness and entertainment, immensity of the works, which attractively affects the audience; 2 ) the use of unique artistic techniques and materials (for example, gunpowder) that were mastered only by one artist, which makes viewers get interested in their work, the basics of their rare artistic craft, and in the future, to understand the unknown cultural signs used in their works; 3) provocative gestures (for example, destruction) that make viewers emotionally respond to the work - to resent the artist's vandalism, support his revolutionary gesture, etc., thereby forming their own attitude to a particular cultural phenomenon; 4) the synthesis of traditional culture, the culture of the past and modern cultural technologies, practices in order to actualize the idea of the interconnectedness of time, that knowledge of the cultural signs of the past helps to better understand the present; 5) finally, the synthesis of two national cultural codes (for example, the union of Western and Eastern visual images), due to which a person of one national culture is able to understand a person of another national culture, since the unknown and incomprehensible were rewritten for him in his native visual language.

\section{References}

An, S.A. (2010). Chelovek v peizazhnoi zhivopisi Kitaia: monografia [A Man in Chinese Landscape Painting: Monograph]. Barnaul AltPA, 209 p.

Andina, T., Onnis, E. (2019). Introduction Chinese Contemporary Art: Between Deconstruction and Construction. In The Philosophy and Art of Wang Guangyi. Bloomsbury Academic, 1-14. DOI: 10.5040/9781350019393-005

Bogodelina, M.E. (2018). Problemy vospriiatiia: sovremennaia kitaiskaia maslianaia zhivopis' glazami zapadnogo zritelia [Perceptual problems: modern Chinese oil painting through the eyes of a Western viewer]. In Art History, 2(88), 107-111. https://doi.org/10.30853/manuscript.2018-2.24

Dubrovskaia, D.V. (2018). Nekitaiskoe iskusstvo Kitaia: impressionizm Sun' Iun’taia, post-imressionizm Pan' Iuilian i "spekuliativnyi art" Vei Duna [Non-Chinese art of China: Sun Yuntai's impressionism, Pan Yuliang's post-impressionism, and Wei Dong's "speculative art."]. In Bulletin of the Institute of Oriental Studies, Russian Academy of Sciences, 4. Moscow, Russian Academy of Sciences, Institute of Oriental Studies, 122-132.

Faryno, J. (2018). Podsolnechnik - semechki [Sunflower - seeds]. In Culture and Text, 2 (33), 7-36.

Gorbutovich, T. (2014). Kartiny kitaiskogo khudozhnika Zeng Fanzhi [Paintings by the Chinese artist Zeng Fanzhi]. Available at: https://www.artifex.ru/\%D0\%B6\%D0\%B8\%D0\%B2\%D0\%BE\%D0\%BF\%D0 $\%$ B8\% D1\% 81\% D1\% 8C /\% D0\% BA\% D0\% B0\% D1\% 80\% D1\% 82\% D0\% B8\% D0\% BD \% D1\% 8B-\% D1\% 86\% D0\% B7\% D1 \% 8D\% D0\% BD-\% D1\% 84\% D0\% B0\% D0\% BD\% D1\% 8C\% D1\% 87\% D0\% $\mathrm{B} 6 \% \mathrm{D} 0 \% \mathrm{~B} 8 /$

Gultekin, T., Peker, B. (2016). Concept of irony, analyses of language and discourse, in the process of social criticism in art. In Idil, Cilt 5, Sayi 19, 5(19), 149-169. doi: 10.7816/idil-05-19-09

Ivanova, Iu.V., Iakovleva, N.F. (2013). Traditsionnaia zhivopis' v sovremennoi kul'ture Kitaia [Traditional painting in modern Chinese culture]. In Scientific notes of ZabSU. Series: Sociological Sciences, 228-237.

Jingyu, Sh. (2019). "Porokhovye kartiny” Tsai Gotsiana kak dialog Vostoka i Zapada v sovremennom iskusstve ["Gunpowder paintings" by Cai Guoqiang as a dialogue between East and West in contemporary art]. In Manuscript, 12 (4). Tambov, Gramota, 156-162. https://doi.org/10.30853/manuscript

Kartseva, E.A. (2017). Sovremennoe iskusstvo v kontekste gosudarstvennoi kul'turnoi politiki. Opyt Kitaia i Rossii [Contemporary art in the context of state cultural policy. The experience of China and Russia]. In Observatoriia kul'tury [Observatory of Culture], 14(2). 157-166. 
Kee, J. (2018). The property of contemporary Chinese art. In Law and Humanity, 12(2), 251-277. DOI: https://doi.org/10.1080/17521483.2018.1524282

Lu, Sh. (2011). Rol' akademicheskogo risunka v sovremennoi sisteme podgotovki khudozhnikov-pedagogov v Kitae [The role of academic drawing in the modern system of training artists and educators in China]. In News of the Southern Federal University. Pedagogical sciences. Available at: http://pedsciencemag.ddk.com.ru/bulletin/pdfVersion?articleIdd=1249

Menezes, C. (2011). Ai Weiwei: Sunflower Seeds. In Studio International. 7 p.

Neglinskaia, M.A. (2020). "Porokhovaia zhvopis"” Tsai Gotsiana: kitaiskaia khudozhestvennaia traditsiia v epokhu postmodernizma ["Gunpowder painting" by Cai Guoqiang: Chinese art tradition in the era of postmodernism]. In Kul'tura i iskusstvo [Culture and Art], 2. 44-50. DOI: 10.7256 / 2454-0625.2020.2.29690 Available at: https://nbpublish.com/library_read_article.php?id=29690

Neglinskaia, M.A. (2010). Ob aktual'nykh tendentsiiakh sovremennogo kitaiskogo iskusstva i perspektivakh ego izucheniia [On current trends in contemporary Chinese art and the prospects for its study]. In Obshchestvo i gosudarstvo v Kitae [Society and the State in China], 40(1). Institute of Oriental Studies, Russian Academy of Sciences, 403-414.

Pashuk, A.A. (2015). Ai Veivei - khudozhnik dissident [Ai Weiwei - a dissident artist]. In Vestnik nauki i obrazovaniia [Herald of Science and Education], 6 (8), 54-56.

Quas, S. (2017). Experimentation in Contemporary art in China: Xu Bing and Zhang Xiaogang, 17 P. Available at: https://www.academia.edu/35191764/Experimentation_in_Contemporary_art_in_China_ $\mathrm{Xu}$ _Bing_and_Zhang_Xiaogang

Sorace, Ch. (2014). China's Last Communist: Ai Weiwei, In Critical Inquiry, Vol. 40(2) (Winter 2014), 396-419.

Starkman,Ch.(2010). TranscriptionofTimeContemporary Art,Community, andtheMuseum. Availableat: file://D: $/ 2019 \% 20-\% 202020 / \% \mathrm{D} 0 \% 9 \mathrm{~A} \% \mathrm{D} 0 \% \mathrm{~B} 8 \% \mathrm{D} 1 \% 82 \% \mathrm{D} 0 \% \mathrm{~B} 0 \% \mathrm{D} 0 \% \mathrm{~B} 9 / \% \mathrm{D} 0 \% \mathrm{BD} \% \mathrm{D} 0 \% \mathrm{~B} 0 \% 20$ $\% \mathrm{D} 0 \% \mathrm{~B} 0 \% \mathrm{D} 0 \% \mathrm{BD} \% \mathrm{D} 0 \% \mathrm{~B} 3 \% \mathrm{D} 0 \% \mathrm{BB} \% \mathrm{D} 0 \% \mathrm{~B} 8 \% \mathrm{D} 0 \% \mathrm{~B} 9 \% \mathrm{D} 1 \% 81 \% \mathrm{D} 0 \% \mathrm{BA} \% \mathrm{D} 0 \% \mathrm{BE} \% \mathrm{D} 0 \% \mathrm{BC} / \mathrm{Od}-$ yssey_Cai_Guo_Qiang_2010.pdf

Vial-Kayser, Ch. (2015). The banquet as a global figure of power in the work of Zeng Fanzhi. In Art\&Media (Korea), 14 (2), 13 p.

Wang, P. (2013). Vliianie russkoi khudozhestvennoi shkoly na razvitie kitaiskoi traditsii zhivopisi maslom [Influence of the Russian art school on the development of the Chinese tradition of oil painting. Scientific notes of ZabSU]. Culturology, 207-214.

Xiaobin, G. (2017). Vliianie russkoi i sovetskoi realisticheskoi zhivopisi v Kitae 1950-1960kh godov: retseptsii i traditsii: dissertatsiia na soiskanie uchenoi stepeni kandidata iskusstvovedeniia [Influence of Russian and Soviet realistic painting in China of the 1950-1960's: receptions and traditions: thesis for PhD in art history]. Moscow.

Zeng Fanzhi's Last supper - one of China's most expensive paintings (2019). In Public delivery. Available at: https://publicdelivery.org/zeng-fanzhi-last-supper/\#Meaning_Analysis

Zhong, Y. Cai Guoqiang, Chen Zhen, Huang Yong Ping (2014). Cosmologists of Chinese Contemporary Art: PhD dissertation. University of California, Berkeley. 248 p.

Zhukovskii, V.I., Koptseva, N.P. (2004). Propozitsii teorii izobrazitel'nogo iskusstva: uchebnoe posobie [Propositions of the theory of art: a textbook]. Krasnoyarsk, Krasnoyarsk State University, 265 p. 


\title{
Национальное и интернациональное \\ в трех произведениях \\ современных китайских художников
}

\section{A.А. Ситникова}

Сибирский федеральный университет

Российская Федерачия, Красноярск

\begin{abstract}
Аннотация. В статье сформулирована и рассмотрена гипотеза, согласно которой благодаря современному постмодернистскому искусству в конце XX - начале XXI века был сформирован единый интернациональный визуальный язык, а ранее загадочные и непонятные основы национальной культуры стали доступными и открытыми на международном уровне. Настоящая концепция рассматривается на основе международной популяризации китайского искусства, так как китайская национальная культура и искусство в течение многих веков оставались загадочными для западных зрителей. Механизмы популяризации национальной культуры раскрыты в статье на основе анализа трех произведений знаменитых современных китайских художников - «Одиссея» Цай Гоцяна, «Цветные вазы» Ай Вэйвэя и «Тайная вечеря» Цзэн Фаньчжи.
\end{abstract}

Ключевые слова: авангардное китайское искусство, Цай Гоцян, Цзэн Фаньчжи, Ай Вэйвэй, традиционное китайской искусство, современное китайское искусство.

Научная специальность: 17.00.09 - теория и история искусства. 